This is the accepted manuscript of the article, which has been published in The Breast. 2019, 48, 65-72. https://doi.org/10.1016/j.breast.2019.09.004

\title{
Occupational exposures and male breast cancer: a nested case-control study in the Nordic countries
}

Talibov M, Hansen J, Heikkinen S, Martinsen JI, Sparen P, Tryggvadottir L, Weiderpass E, Pukkala E

\section{ABSTRACT}

Background. Male breast cancer (MBC) is a rare and understudied disease. There is limited evidence on association between environmental and occupational agents and MBC. Some similarities in risk factors may be shared with female breast cancer. We evaluated solvents, metals, exhaust gases and other agents in relation to $\mathrm{MBC}$ within the large Nordic Occupational Cancer Study (NOCCA).

Methods. The study included 1,469 MBC cases and 7,345 controls from Finland, Iceland and Sweden, matched for the date of birth, sex and country. Cases were identified through national cancer registries. Data on occupation and other demographic indicators were collected from census records and population registries. Overall, 24 occupational exposures were assessed. Exposure estimates were assigned by linking job titles to job-exposure matrices (NOCCA-JEM). Odds ratios $(\mathrm{OR})$ and $95 \%$ confidence intervals $(95 \% \mathrm{Cl}$ ) were estimated by using conditional logistic regression models.

Results. Significantly decreased overall OR was observed for physical workload $(O R=0.78$, $95 \% \mathrm{Cl}$ 0.67-0.91). Protective effect of physical workload was stronger by increasing exposure level with significant dose-response relationship ( $p$-trend<0.01). Non-significantly increased ORs were observed for trichloroethylene, iron, lead, chromium, welding fumes and wood dust, and decreased ORs for asbestos, silica dust and perchloroethylene. However, these results were not consistent across all analyses.

Conclusions. The current study showed $20-25 \%$ protective effect for physical workload at work, while no strong evidence for other agents was observed.

Keywords: case-control study; job-exposure matrix; male breast cancer; NOCCA; occupational exposure

\section{BACKGROUND}

Male breast cancer (MBC) is a rare and understudied disease, which accounts for about $1 \%$ of all breast cancers [1]. The incidence of MBC has slightly increased over the last decades in the Nordic countries with 159 new cases diagnosed in 2015 (Figure 1) [2]. 
Family history of breast cancer and genetic mutations, especially in the BRCA2 gene, and to a lesser extent in BRCA1, CHEK2 and PALB2 genes are risk factors for MBC [1]. Some hormone-related factors such as Klinefelter's syndrome, obesity, testicular abnormalities, and elevated estrogen levels have also been linked to an increased risk of MBC [3-6].

Environmental and occupational agents are also suspected risk factors of MBC. Some of these agents are highly lipophilic and may accumulate in adipose tissue of the breast initiating carcinogenesis through genotoxic mechanisms [7]. Associations for perchloroethylene, 1,2 dichloroethylene and vinyl chloride were also suggested in a study of Marine Corps Base Camp Lejeune, North Carolina [8]. Occupational exposure to trichloroethylene was significantly associated with $\mathrm{MBC}$, and possible associations with benzene and ethylene glycol were reported in a European multi-centre case-control study [9]. A registry based study from Denmark observed an increased risk for $\mathrm{MBC}$ in jobs related to traffic exhaust exposures [10].

Radiation has been linked to $\mathrm{MBC}$ in studies of atomic bomb survivors [11, 12]. Occupational exposure to magnetic fields was associated with an increased risk of MBC among Canadian men [13]. Finally, it has been suggested that exposure to light-at-night through night work may increase the risk for MBC [14].

The aim of this large study was to evaluate occupational exposures in relation to $M B C$ in selected Nordic countries.

\section{METHODS}

We conducted a case-control study nested within the Nordic Occupational Cancer Study (NOCCA) cohort [15]. The NOCCA cohort includes 14.9 million persons from Denmark, Finland, Iceland, Norway and Sweden, and it has been assembled by linking various population registries and census records with national cancer registries. Data from Denmark and Norway was not included in this study because we did not have an access to individual level data from these countries. The persons were included in the NOCCA cohort on 1 January of the year following the first available census where they participated, provided they were 30-64 years old. They were followed-up till the date of emigration, death or December 31 of 2005 in Finland and Sweden and 2004 in Iceland [15].

\section{Study participants}

The study included 1,469 incident MBC cases diagnosed between 1961 and 2005 in Finland, Iceland and Sweden.

Five controls for each case were randomly selected from the NOCCA cohort. Cases and controls were matched for country, sex and year of birth. Study participants had to be 20 years or older at the date of diagnosis of the case ("index date"), and had to have at least one census record before index date. 


\section{Data collection}

Cancer cases were identified from national cancer registries [15]. The Finnish Cancer Registry was established in 1953, and cases were registered based on reports from clinical and pathological hospital departments, private clinics, general practitioners and death registry records. The Icelandic Cancer Registry started in 1955, and case reporting was based on records from pathology laboratories complemented by information from cytology and hematology laboratories, hospitals, health centers, and death certificates. In Sweden, reporting of cancer cases during 1958-1982 was based on reports from hospitals and pathologists. Private practitioners were required to report cancer cases since 1983 . Unlike other Nordic countries, Sweden does not use death certificates information for cancer registration [15].

Information on occupation held during the follow-up was obtained from computerized census records. Computerized census records were available from 1960 and later censuses in Sweden and from 1970 and later censuses in Finland. The only computerized census record available in Iceland was from 1981 census. Census questionnaires were selfadministered and included questions on economic activity, occupation and industry. In Finland and Sweden, they were filled in by the heads of households, while each member of household who was at least 17 years old, personally filled in the questionnaire in Iceland [15].

Data on date of birth and emigration were obtained from Central Population Registries of these countries. Data from various registries were linked by using unique personal identification numbers used in the Nordic countries. This ensured complete ascertainment of relevant events for each person included in the study, because the possibility of error in identifiers is extremely small [15].

\section{Exposure assignment}

Occupational exposure estimates were assigned by linking job titles of study participants to the NOCCA job-exposure matrix (NOCCA-JEM). The NOCCA-JEM was developed by expert panel consisting of industrial hygienists/exposure experts from each Nordic country [16]. It assigns exposure prevalence $(P)$ and annual average exposure $(L)$ for 29 occupational agents, which are confirmed or suspected carcinogens, in more than 300 occupational categories in four time periods: 1945-1959, 1960-1974, 1975-1984, 1985-1994 [16].

Extremely low-frequency magnetic field (ELF-MF) exposure was assigned by using ELF-MF JEM described by Talibov et al [17]. 


\section{Statistical analysis}

We assigned a product of $\mathrm{P}$ and $\mathrm{L}(\mathrm{P} \times \mathrm{L})$ to each year over the employment period of study participants. These estimates were then summed up to derive cumulative exposure index. This procedure was repeated for all exposure agents included in the current analysis.

Exact start and end dates of employment were not available for study participants. Therefore, we assumed that they started employment at the age of 20 and ended at the age of 65 (typical retirement age in the Nordic countries) or index date, whichever came first. If a person had different occupations in different censuses, we assumed that he/she changed occupation midway of known census years.

Odds ratios (OR) and $95 \%$ confidence intervals $(95 \% \mathrm{Cl}$ ) were estimated by conditional logistic regression models. Cumulative exposure indices of exposures were categorized to dichotomous and polytomous exposures. The latter was defined by using $50^{\text {th }}$ and $90^{\text {th }}$ percentiles of exposure distribution among exposed controls as cut-points. Unexposed persons were used as a reference category both for dichotomous and polytomous exposures. Ordinal exposure metrics were treated as continuous in regression models in order to obtain an estimate of the slope and associated p-values ( $p$-trend).

We used single and multiple exposure models to obtain risk estimates. In single exposure models (Model 1), we included each exposure agent one at a time, while in a multiple exposure model (Model 2), all exposure agents were added in the model simultaneously. If exposure agents were highly correlated (Spearman correlation $>0.80$ ), we included them in separate models. To evaluate robustness of the main results, we performed sensitivity analyses with 5- and 10-year lag-time, analysis with tertile categorization and adjustment for lifestyle related factors. The lag-time analyses were performed under the assumption that cancer may develop over a number of years, and recent exposures may not be related to the disease. Therefore, in lag-time analyses, we did not count exposures occurring 5 and 10 years before the index date, respectively. In order to adjust for multiple comparisons, we used Holm's method which was described elsewhere [18].

Adjustment for lifestyle factors could be made only for the Finnish part of the data, because lifestyle factors by occupation were available from the Finnish job-exposure matrix, FINJEM [19]. FINJEM provides data on proportions of daily smokers in each occupation, men drinking at least 8 and women at least 5 portions of alcohol weekly, those who fulfil fewer than 3 of 4 recommended dietary habits, those who have leisure time exercise less than twice a week, and those whose body mass index is $25 \mathrm{~kg} / \mathrm{m}^{2}$ or higher. Lifestyle related factors in FINJEM are based on data from annual surveys of adult population conducted from 1978 to 2014 by the Finnish National Institute for Health and Welfare [20]. Finally, we restricted analysis to the age group 30-70 years at index date, assuming that occupational exposures are unlikely to be related to $\mathrm{MBC}$ in younger or older persons. 
All analyses were performed by using R version 3.5.1 (R Core Team. 2017. R: A language and environment for statistical computing. R Foundation for Statistical Computing, Vienna, Austria. https://www.R-project.org/) software.

\section{RESULTS}

About $77 \%$ of the cases and controls were from Sweden, $21 \%$ from Finland and only $2 \%$ from Iceland. About $60 \%$ were $60-80$ years old at diagnosis (Table 1). Metals were highly correlated with welding fumes and benzo[a]pyrene (Spearman correlation $>0.80$ ), toluene with benzene and methylene chloride, benzene with gasoline (Supplementary Table 1).

\section{Solvents}

We evaluated six organic solvents in this analysis (Table 2). Non-significantly increased OR was observed for trichloroethylene $(1.15,95 \% \mathrm{Cl} 0.79-1.68)$ and decreased $\mathrm{OR}$ for perchloroethylene $(0.52,95 \% \mathrm{Cl} 0.28-0.96)$, only in multiple exposure models (Table 2). These results did not change in analyses of polytomous exposure (Table 3 ).

\section{Metals}

Overall OR was non-significantly elevated for iron (1.39, 05\% Cl 0.70-2.75), chromium (1.19, $95 \% \mathrm{Cl} 0.89-1.60)$ and lead $(1.23,95 \% \mathrm{Cl} 0.91-1.64)$ only in a multiple exposure models (Table 2). ORs remained elevated for iron and lead also in analyses of polytomous exposures, while inverse association was observed for chromium (Table 3).

\section{Exhaust gases}

We evaluated diesel engine exhaust and gasoline exhaust in this group and these agents were not related to $\mathrm{MBC}$ risk (Tables 2 and 3 ).

\section{Other agents}

Significantly decreased ORs were observed for physical workload at work $(0.76,95 \% \mathrm{Cl} 0.67$ 0.85 from single exposure model and $0.78,95 \% \mathrm{Cl} 0.67-0.91$ from multiple exposure model), and for asbestos $(0.83,95 \% \mathrm{Cl} 0.73-0.95)$ and silica dust $(0.79,95 \% \mathrm{Cl} 0.65-0.96)$ only from single exposure models (Table 2). Protective effect of physical workload was stronger by increasing exposure level with statistically significant dose-response relationship ( $p$ trend<0.01) (Table 3).

Non-significantly increased overall ORs were observed for welding fumes $(1.39,95 \% \mathrm{Cl} 0.70$ 2.75 ), and a positive trend ( $p=0.02$ ) was observed by increasing exposure levels (Table 3 ) in the multiple exposure model. 


\section{Sensitivity analyses}

In analyses with 5- and 10-year lag-time, overall ORs remained non-significantly elevated for trichloroethylene, iron, lead and welding fumes (data not shown). OR for chromium was statistically significantly elevated $(1.37,95 \% \mathrm{Cl} 1.02-1.84)$ in a 10 -year lag-time analysis in a multiple exposure model. However, analysis of polytomous exposure showed inverse relationship for chromium $\left(\mathrm{OR}=1.46,95 \% \mathrm{Cl} 1.05-2.06\right.$ for the category $<50^{\text {th }}$ percentile; $\mathrm{OR}=1.21,95 \% \mathrm{Cl} 0.70-2.09$ for $50^{\text {th }}-90^{\text {th }}$; and $\mathrm{OR}=0.69,95 \% \mathrm{Cl} 0.24-2.02$ for $>90^{\text {th }}$ percentile).

Protective effect of physical workload was observed in both lag-time analyses (OR=0.79, $95 \% \mathrm{Cl} 0.68-0.91$ in 5-year lag-time and $\mathrm{OR}=0.78,95 \% \mathrm{Cl} 0.67-0.91$ in 10-year lag-time).

The main observations did not change in the analyses with tertile categorization or in the analyses restricted to age group 30-70 years. Adjusting for lifestyle factors in the Finnish data has not considerably changed OR estimates from the main analyses (Supplementary Table 2).

\section{DISCUSSION}

The current study showed positive associations for trichloroethylene, iron, chromium, lead, welding fumes and wood dust, and negative associations for physical workload, asbestos, silica dust and perchloroethylene. However, most of these associations were not consistent across sensitivity analyses. Overall OR for chromium was significant only in a 10-year lagtime analysis. Only associations for physical workload were statistically significant across all analyses with dose-response relationship.

Physical activity has been associated with reduced risk of breast cancer in women in previous studies [21, 22]. In a meta-analysis of 31 prospective studies, average breast cancer risk reduction was $12 \%$ for leisure time and occupational physical activity combined, and $10 \%$ for occupational physical activity alone [22]. In another study, 25\% average risk reduction was observed among physically active women compared to the least active women [21]. Protective effect of physical activity is likely to happen through lowering the levels of hormones, such as insulin and estrogen and of certain growth factors that have been associated with breast cancer [23]. To our knowledge, there have been no studies assessing effect of physical activity on MBC risk. However, because hormones and growth factors are also risk factors of $M B C$ [1], mechanism suggested for protective effect of physical activity among women is likely to be the same among men.

Our findings for perchloroethylene and ELF-MF is in contrast with findings from Ruckart et al (2015) [8] and Grundy et al (2016) [13] who reported non-significantly increased ORs for perchloroethylene ( $\mathrm{OR}=1.20,95 \% \mathrm{Cl}$ 0.16-5.89, based on 2 exposed cases and 8 controls) and for ELF-MF $\geq 0.6 \mu \mathrm{T}$ (micro Tesla) (OR=1.80, 95\% Cl 0.82-3.95). In our study, MBC was 
inversely associated with perchloroethylene and ELF-MF, although not consistently in all analyses. Our finding for trichloroethylene was consistent with findings from Ruckart et al [8] and Laouali et al [9]. Laouali et al observed significantly increased OR for cumulative trichloroethylene $>23.9 \mathrm{ppm}$ years $(\mathrm{OR}=2.1,95 \% \mathrm{Cl} 1.2-4.0$, p-trend $<0.01$ ) compared to unexposed. In our study, OR for trichloroethylene $>23.9$ ppm years was 1.14 ( $95 \% \mathrm{Cl} 0.87$ $1.50)$ in a single exposure model and $1.62(95 \% \mathrm{Cl} 0.97-2.71)$ in a multiple exposure model.

Night work was not associated with breast cancer in this study in contrast to previous studies showing increased risk of breast cancer in women [24]. Previous studies also showed that frequency of night shift work, particularly a number of consecutive shifts, may be an important predictor of its carcinogenicity $[25,26]$. Such exposure details for night shift work is not captured by the NOCCA-JEM. This may explain the inconsistency between the results for night work exposure.

Accuracy and completeness of cancer incidence data is one of the strengths of the current study. Validation studies demonstrated high level of completeness, comparability, accuracy and timeliness of cancer registration in the Nordic countries [27]. Other advantages of the study are accuracy of job titles and quantitative exposure assignment by using JEMs. Previous validity studies demonstrated high accuracy of occupational classifications based on census records in the Nordic countries $[28,29]$. By linking job histories to JEMs, we were able to control for the effect of many concomitant agents simultaneously.

The main limitation of the study is potential exposure misclassification which could happen because of the following reasons. First, we do not have lifetime occupational history, but rather assume that study subjects stay in same job as assessed by the censuses, which however, is unlikely to cause major misclassification because occupational mobility in the Nordic countries has been low $[15,28]$. Second, the JEMs used in the current study assign average exposure to all members of the occupation, while exposure heterogeneity within the occupation might be substantial. In addition, imputations were made based on four computerized census records from Sweden (77\% of study participants) and three census records from Finland (21\%). In Iceland, the only available computerized census record was from 1981 . However, Icelandic data contributed to less than $2 \%$ of all data included in this study (Table 1).

We used the same exposure estimation method for cases and controls in this study. Therefore, exposure estimation was independent of disease status of study participants, and exposure misclassification was likely to be non-differential. Bias from non-differential exposure is generally towards the null for dichotomous exposures [30]. When exposure has more than two categories, biases away from the null occur only for intermediate exposure categories, but misclassified odds ratio for the highest category will be towards the null [31]. Therefore, overall odds ratios from Table 2 and odds ratios for highest exposure levels from Table 3 are likely to be underestimated and true estimate were likely to be larger, if misclassification would occur. 
Chance findings related to multiple comparisons was another issue to be considered in this study. In order to adjust for multiple comparisons, we applied Holm's method by comparing p-values to critical values smaller than conventional 0.05 . Details of selection of new critical values are described elsewhere [18]. This procedure showed that associations observed for physical workload from single and multiple exposure models, and ultraviolet radiation only from single exposure model remained statistically significant after adjustment suggesting that these findings were unlikely to be chance findings due to multiple comparisons.

We could not control for smoking, alcohol, leisure time physical activity, and obesity in the main analyses because we did not have data on these factors. However, we do not think that lifestyle factors would be strong confounders in this study because there is limited evidence that they are strong risk factors of $\mathrm{MBC}$. Obesity was moderately linked to increased $\mathrm{MBC}$ risk in previous studies [4, 6]. Further, alcohol and tobacco smoking were not associated with $\mathrm{MBC}$ in a recent pooling study [32]. Finally, additional adjustments for lifestyle factors in the Finnish part of the data did not change the main results in our study.

In conclusion, this study showed associations with MBC risk for iron, chromium, lead, welding fumes, wood dust, physical workload and perchloroethylene. While most of these results were inconsistent across sensitivity analyses, $20-25 \%$ protective effect of physical workload was significant in all analyses with exposure-response trend.

\section{ACKNOWLEDGEMENT}

The authors thank the Nordic Occupational Cancer Studies (NOCCA) project members for the development of NOCCA cohort data and job-exposure matrix.

\section{ETHICAL APPROVAL}

The Icelandic study was approved by the National Bioethics Committee of Iceland (VSN- 05082) and the Data Protection Authority (PV 2006070395). In Sweden and Finland, neither ethical committee approval nor informed consent from study participants is required for registry based studies.

\section{CONFLICT OF INTERESTS}

The authors declare no conflict of interests in connection with this study. 


\section{FUNDING}

This study did not receive any specific grant from funding agencies in the public, commercial, or not-for-profit sectors.

The NOCCA project has been funded by the Nordic Cancer Union.

\section{DISCLAIMER}

Where authors are identified as personnel of the International Agency for Research on Cancer / World Health Organization, the authors alone are responsible for the views expressed in this article and they do not necessarily represent the decisions, policy or views of the International Agency for Research on Cancer / World Health Organization.

\section{REFERENCES}

[1] Giordano SH. Breast Cancer in Men. N Engl J Med 2018;378(24):2311-20.

[2] Danckert B, Ferlay J, Engholm G , Hansen HL, Johannesen TB, Khan S, Køtlum JE, Ólafsdóttir E, Schmidt LKH, Virtanen A and Storm HH. NORDCAN: Cancer Incidence, Mortality, Prevalence and Survival in the Nordic Countries, Version 8.2 (26.03.2019). Association of the Nordic Cancer Registries. Danish Cancer Society. Available from http://www.ancr.nu, accessed on 22/04/2019.

[3] Brinton LA, Key TJ, Kolonel LN, Michels KB, Sesso HD, Ursin G, et al. Prediagnostic Sex Steroid Hormones in Relation to Male Breast Cancer Risk. J Clin Oncol 2015; 33(18):2041-50.

[4] Brinton LA, Cook MB, McCormack V, Johnson KC, Olsson H, Casagrande JT, et al. Anthropometric and hormonal risk factors for male breast cancer: male breast cancer pooling project results. J Natl Cancer Inst 2014;106(3):djt465.

[5] Thomas DB, Jimenez LM, McTiernan A, Rosenblatt K, Stalsberg H, Stemhagen A, et al. Breast cancer in men: risk factors with hormonal implications. Am J Epidemiol 1992;135(7):734-48.

[6] Brinton LA, Carreon JD, Gierach GL, McGlynn KA, Gridley G. Etiologic factors for male breast cancer in the U.S. Veterans Affairs medical care system database. Breast Cancer Res Treat 2010;119(1):185-92. 
[7] Labreche FP, Goldberg MS. Exposure to organic solvents and breast cancer in women: a hypothesis. Am J Ind Med 1997;32(1):1-14.

[8] Ruckart PZ, Bove FJ, Shanley E, 3rd, Maslia M. Evaluation of contaminated drinking water and male breast cancer at Marine Corps Base Camp Lejeune, North Carolina: a case control study. Environ Health 2015;14:74.

[9] Laouali N, Pilorget C, Cyr D, Neri M, Kaerlev L, Sabroe S, et al. Occupational exposure to organic solvents and risk of male breast cancer: a European multicenter case-control study. Scand J Work Environ Health 2018;44(3):310-22.

[10] Hansen J. Elevated risk for male breast cancer after occupational exposure to gasoline and vehicular combustion products. Am J Ind Med 2000;37(4):349-352.

[11] Little MP, McElvenny DM. Male Breast Cancer Incidence and Mortality Risk in the Japanese Atomic Bomb Survivors - Differences in Excess Relative and Absolute Risk from Female Breast Cancer. Environ Health Perspect 2017;125(2):223-9.

[12] Ron E, Ikeda T, Preston DL, Tokuoka S. Male breast cancer incidence among atomic bomb survivors. J Natl Cancer Inst 2005;97(8):603-5.

[13] Grundy A, Harris SA, Demers PA, Johnson KC, Agnew DA, Villeneuve PJ. Occupational exposure to magnetic fields and breast cancer among Canadian men. Cancer Med 2016;5(3):586-96.

[14] Weiss JR, Moysich KB, Swede H. Epidemiology of male breast cancer. Cancer Epidemiol Biomarkers Prev 2005; 14(1): 20-26.

[15] Pukkala E, Martinsen JI, Lynge E, Gunnarsdottir HK, Sparen P, Tryggvadottir L, et al. Occupation and cancer - follow-up of 15 million people in five Nordic countries. Acta Oncol 2009;48(5):646-790.

[16] Kauppinen T, Heikkila P, Plato N, Woldbaek T, Lenvik K, Hansen J, et al. Construction of job-exposure matrices for the Nordic Occupational Cancer Study (NOCCA). Acta Oncol 2009;48(5):791-800. 
[17] Talibov M, Guxens M, Pukkala E, Huss A, Kromhout H, Slottje P, et al. Occupational exposure to extremely low-frequency magnetic fields and electrical shocks and acute myeloid leukemia in four Nordic countries. Cancer Causes Control 2015;26(8):1079-85.

[18] Holm S. A simple sequentially rejective multiple test procedure. Scand J Stat 1979;6(2):65-70.

[19] Kauppinen T, Toikkanen J, Pukkala E. From cross-tabulations to multipurpose exposure information systems: a new job-exposure matrix. Am J Ind Med 1998;33(4):409-17.

[20] National Institute for Health and Welfare. Health behavior and health among the Finnish adult population. Tampere, Finland: Spring; 2015.

[21] Lynch BM, Neilson HK, Friedenreich CM. Physical activity and breast cancer prevention. Recent Results Cancer Res 2011;186:13-42.

[22] Wu Y, Zhang D, Kang S. Physical activity and risk of breast cancer: a meta-analysis of prospective studies. Breast Cancer Res Treat 2013;137(3):869-82.

[23] Winzer BM, Whiteman DC, Reeves MM, Paratz JD. Physical activity and cancer prevention: a systematic review of clinical trials. Cancer Causes Control 2011;22(6):811-26.

[24] Åkerstedt T, Knutsson A, Narusyte J, Svedberg P, Kecklund G, Alexandersson K. Night work and breast cancer in women: a Swedish cohort study. BMJ Open 2015;5(4):e008127.

[25] Hansen J, Lassen CF. Nested case-control study of night shift work and breast cancer risk among women in in the Danish military. Occup Environ Med. 2012;69:551-6.

[26] Lie J-A S, Kjuus H, Zienolddiny S, Haugen A, Stevens RG, Kjaerheim K. Night work and breast cancer risk among Norwegian nurses: assessment by different exposure metrics. Am J Epidemiol. 2011;173(11):1272-9.

[27] Pukkala E, Engholm G, Hojsgaard Schmidt LK, Storm H, Khan S, Lambe M, et al. Nordic Cancer Registries - an overview of their procedures and data comparability. Acta Oncol 2018;57(4):440-55.

[28] Kolari R. Occupational Mortality in Finland 1975/1980/1985. Helsinki, Finland: Statistics Finland; 1989. 
[29] Statistics Norway. Population and Housing Census 1970. Evaluation Survey. Oslo, Norway: Statistics Sentralbyrå; 1970.

[30] Rothman KJ, Greenland S, Lash TL. Validity in Epidemiological Studies. In: Rothman KJ, Greenland S, Lash TL. Modern epidemiology: Third edition. Wolters Kluwer: Lippincott Williams \& Wilkins; 2011, p. 128-148.

[31] Birkett NJ. Effect of nondifferential misclassification on estimates of odds ratios with multiple levels of exposure. Am J Epidemiol 1992;136(3):356-62.

[32] Cook MB, Guenel P, Gapstur SM, van den Brandt PA, Michels KB, Casagrande JT, et al. Tobacco and alcohol in relation to male breast cancer: an analysis of the male breast cancer pooling project consortium. Cancer Epidemiol Biomarkers Prev 2015;24(3):520-31. 
Figure 1. Age-standardized 5-year floating averages of incidence rates of male breast cancer in 1960-2015 in the Nordic countries. World Standard Population was used as a standard population. Source: NORDCAN data [2].

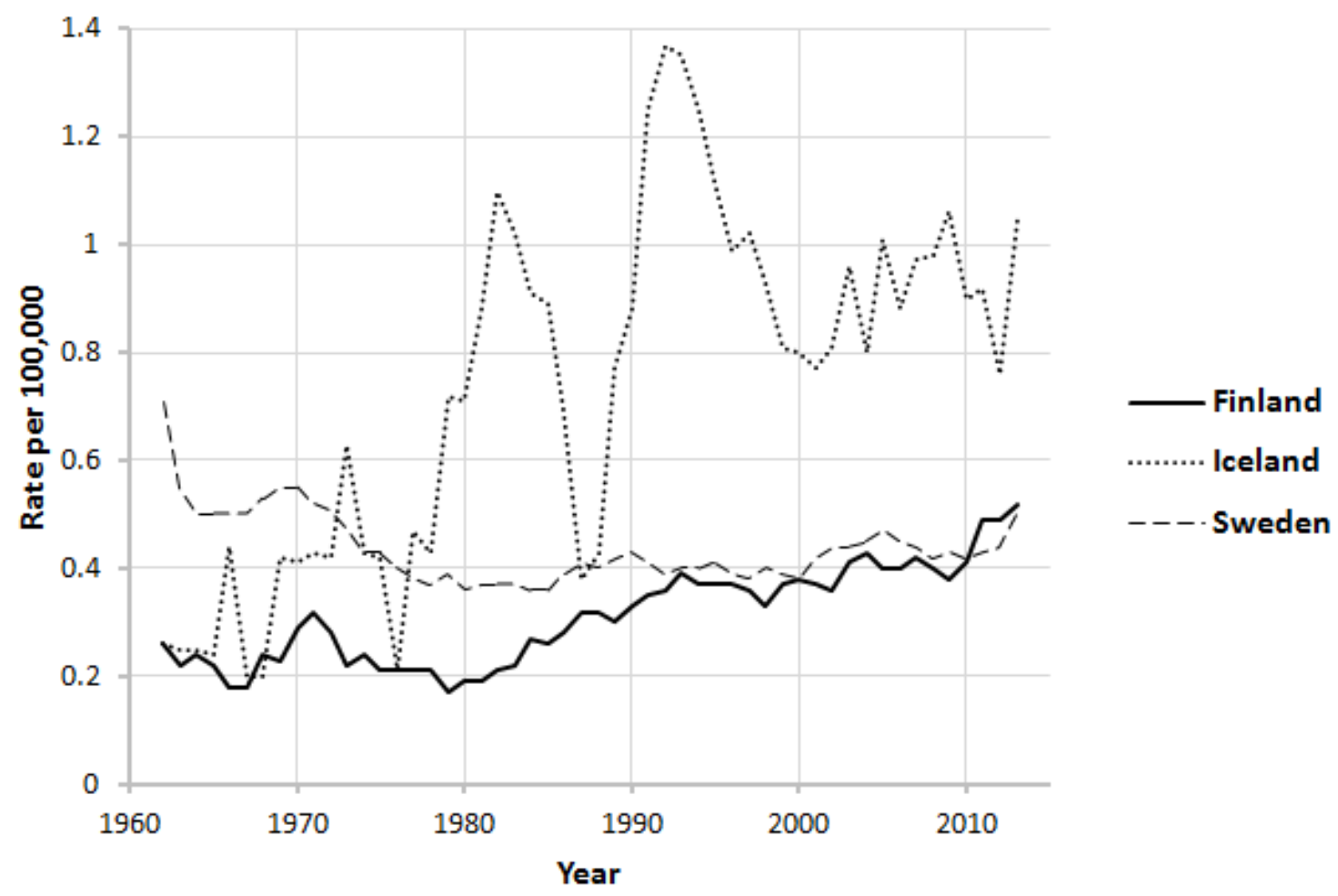

Table 1. Selected demographic characteristics of MBC study population.

\begin{tabular}{|l|r|r|r|r|}
\hline \multirow{2}{*}{ Characteristics } & \multicolumn{2}{|c|}{ Cases (n=1,469) } & \multicolumn{2}{c|}{ Controls (7,345) } \\
\cline { 2 - 5 } & \multicolumn{1}{|c|}{$\mathrm{n}$} & \multicolumn{1}{c|}{$\mathrm{N}$} & \multicolumn{1}{c|}{$\%$} \\
\hline Country & & & & \\
\hline Finland & 308 & 21.0 & 1540 & 21.0 \\
\hline Iceland & 28 & 1.9 & 140 & 1.9 \\
\hline Sweden & 1133 & 77.1 & 5665 & 77.1 \\
\hline & & & & \\
\hline Age at diagnosis & & & & \\
\hline$\leq 40$ & 17 & 1.2 & 82 & 1.2 \\
\hline $41-60$ & 371 & 25.3 & 1849 & 25.3 \\
\hline $61-80$ & 868 & 59.1 & 4339 & 59.1 \\
\hline$\geq 80$ & 213 & 14.5 & 1075 & 14.5 \\
\hline Mean (Median) & & & & $67.6(68.6)$ \\
\hline & & & \multicolumn{4}{|l}{} \\
\hline Year of birth & & & & \\
\hline$\leq 1920$ & 725 & 49.4 & 3625 & 49.4 \\
\hline $1921-1930$ & 346 & 23.6 & 1730 & 23.6 \\
\hline $1931-1940$ & 209 & 14.2 & 1045 & 14.2 \\
\hline $1941-1950$ & 142 & 9.7 & 710 & 9.7 \\
\hline $1951-1960$ & 46 & 3.2 & 235 & 3.2 \\
\hline
\end{tabular}


Table 2. Odds ratios $(\mathrm{OR})$ and $95 \%$ confidence intervals $(95 \% \mathrm{Cl})$ for binary exposure to selected occupational agents and breast cancer in men.

\begin{tabular}{|c|c|c|c|c|c|c|c|c|}
\hline \multirow{2}{*}{ Agent } & \multirow{2}{*}{$\begin{array}{c}\text { Case, } \\
\text { N }\end{array}$} & \multirow{2}{*}{$\begin{array}{c}\text { Control, } \\
\mathbf{N}\end{array}$} & \multicolumn{3}{|c|}{ Model $1^{\text {a }}$} & \multicolumn{3}{|c|}{ Model $2^{b c}$} \\
\hline & & & OR & $95 \% \mathrm{Cl}$ & p-value & OR & $95 \% \mathrm{Cl}$ & p-value \\
\hline \multicolumn{9}{|l|}{ Solvents } \\
\hline \multicolumn{9}{|l|}{ Benzene } \\
\hline never & 1355 & 6756 & 1.00 & & & & & \\
\hline ever & 114 & 589 & 0.96 & $0.78-1.19$ & 0.71 & 0.99 & $0.72-1.37$ & 0.98 \\
\hline \multicolumn{9}{|c|}{ 1,1,1-trichloroethane } \\
\hline never & 1288 & 6441 & 1.00 & & & & & \\
\hline ever & 181 & 904 & 1.01 & $0.84-1.20$ & 0.95 & 1.02 & $0.67-1.57$ & 0.92 \\
\hline \multicolumn{9}{|c|}{ Methylene chloride } \\
\hline never & 1356 & 6772 & 1.00 & & & & & \\
\hline ever & 113 & 573 & 0.99 & $0.80-1.22$ & 0.89 & 0.97 & $0.58-1.64$ & 0.92 \\
\hline \multicolumn{9}{|c|}{ Perchloroethylene } \\
\hline never & 1455 & 7231 & 1.00 & & & & & \\
\hline ever & 14 & 114 & 0.61 & $0.35-1.06$ & 0.08 & 0.52 & $0.28-0.96$ & 0.04 \\
\hline \multicolumn{9}{|l|}{ Toluene } \\
\hline never & 1351 & 6749 & 1.00 & & & & & \\
\hline ever & 118 & 596 & 0.99 & $0.80-1.22$ & 0.89 & 0.96 & $0.60-1.53$ & 0.86 \\
\hline \multicolumn{9}{|c|}{ Trichloroethylene } \\
\hline never & 1349 & 6738 & 1.00 & & & & & \\
\hline ever & 120 & 607 & 0.99 & $0.81-1.22$ & 0.94 & 1.15 & $0.79-1.68$ & 0.46 \\
\hline \multicolumn{9}{|l|}{ Metals } \\
\hline \multicolumn{9}{|c|}{ Chromium } \\
\hline never & 1224 & 6100 & 1.00 & & & & & \\
\hline ever & 245 & 1245 & 0.99 & $0.85-1.15$ & 0.80 & 1.19 & $0.89-1.60$ & 0.24 \\
\hline \multicolumn{9}{|l|}{ Iron } \\
\hline never & 1266 & 6286 & 1.00 & & & & & \\
\hline ever & 203 & 1059 & 0.95 & $0.81-1.12$ & 0.54 & 1.39 & $0.70-2.75$ & 0.35 \\
\hline \multicolumn{9}{|l|}{ Nickel } \\
\hline never & 1268 & 6273 & 1.00 & & & & & \\
\hline ever & 201 & 1072 & 0.93 & $0.79-1.09$ & 0.39 & 0.71 & $0.35-1.41$ & 0.32 \\
\hline \multicolumn{9}{|l|}{ Lead } \\
\hline never & 1183 & 5896 & 1.00 & & & & & \\
\hline ever & 286 & 1449 & 0.98 & $0.85-1.14$ & 0.83 & 1.23 & $0.91-1.64$ & 0.17 \\
\hline \multicolumn{9}{|c|}{ Exhaust gas } \\
\hline \multicolumn{9}{|c|}{ Diesel exhaust } \\
\hline never & 1192 & 5927 & 1.00 & & & & & \\
\hline ever & 277 & 1418 & 0.96 & $0.83-1.11$ & 0.58 & 0.95 & $0.71-2.36$ & 0.57 \\
\hline \multicolumn{9}{|c|}{ Gasoline exhaust } \\
\hline never & 1398 & 6989 & 1.00 & & & & & \\
\hline ever & 71 & 356 & 0.99 & $0.77-1.30$ & 0.98 & 1.29 & $0.76-2.65$ & 0.28 \\
\hline
\end{tabular}




\begin{tabular}{|c|c|c|c|c|c|c|c|c|}
\hline \multicolumn{9}{|c|}{ Other agents } \\
\hline \multicolumn{9}{|c|}{ Formaldehyde } \\
\hline never & 1313 & 6472 & 1.00 & & & & & \\
\hline ever & 156 & 873 & 0.89 & $0.75-1.08$ & 0.25 & 0.97 & $0.77-1.22$ & 0.79 \\
\hline \multicolumn{9}{|c|}{ Benzo[a]pyrene } \\
\hline never & 1310 & 6476 & 1.00 & & & & & \\
\hline ever & 159 & 869 & 0.91 & $0.75-1.08$ & 0.26 & 0.75 & $0.54-1.05$ & 0.09 \\
\hline \multicolumn{9}{|c|}{ Bitumen fumes } \\
\hline never & 1452 & 7237 & 1.00 & & & & & \\
\hline ever & 17 & 108 & 0.79 & $0.47-1.33$ & 0.36 & 0.99 & $0.58-1.69$ & 0.97 \\
\hline \multicolumn{9}{|l|}{ Asbestos } \\
\hline never & 1143 & 5456 & 1.00 & & & & & \\
\hline ever & 326 & 1889 & 0.83 & $0.73-0.95$ & 0.01 & 0.89 & $0.73-1.10$ & 0.29 \\
\hline \multicolumn{9}{|c|}{ Silica dust } \\
\hline never & 1334 & 6490 & 1.00 & & & & & \\
\hline ever & 135 & 855 & 0.79 & $0.65-0.96$ & 0.02 & 0.97 & $0.74-1.27$ & 0.81 \\
\hline \multicolumn{9}{|c|}{ Sulphur dioxide } \\
\hline never & 1437 & 7142 & 1.00 & & & & & \\
\hline ever & 32 & 203 & 0.79 & $0.55-1.16$ & 0.24 & 0.91 & $0.60-1.37$ & 0.65 \\
\hline \multicolumn{9}{|c|}{ Night-shift work } \\
\hline never & 1136 & 5533 & 1.00 & & & & & \\
\hline ever & 333 & 1812 & 0.89 & $0.78-1.02$ & 0.09 & 0.92 & $0.78-1.07$ & 0.27 \\
\hline \multicolumn{9}{|l|}{ ELF-MF } \\
\hline never & 844 & 4188 & 1.00 & & & & & \\
\hline ever & 625 & 3157 & 0.98 & $0.87-1.10$ & 0.73 & 0.98 & $0.85-1.13$ & 0.81 \\
\hline \multicolumn{9}{|c|}{ Physical workload } \\
\hline never & 594 & 2430 & 1.00 & & & & & \\
\hline ever & 875 & 4915 & 0.76 & $0.67-0.85$ & $<0.01$ & 0.78 & $0.67-0.91$ & $<0.01$ \\
\hline \multicolumn{9}{|c|}{ Wood dust } \\
\hline never & 1358 & 6770 & 1.00 & & & & & \\
\hline ever & 111 & 575 & 0.98 & $0.79-1.21$ & 0.84 & 1.14 & $0.88-1.48$ & 0.32 \\
\hline \multicolumn{9}{|c|}{ Welding fumes } \\
\hline never & 1266 & 6286 & 1.00 & & & & & \\
\hline ever & 203 & 1059 & 0.95 & $0.81-1.13$ & 0.58 & 1.39 & $0.70-2.75$ & 0.35 \\
\hline \multicolumn{9}{|c|}{ Ultraviolet radiation } \\
\hline never & 1010 & 4633 & 1.00 & & & & & \\
\hline ever & 459 & 2712 & 0.80 & $0.71-0.91$ & $<0.01$ & 0.89 & $0.77-1.04$ & 0.13 \\
\hline
\end{tabular}

Abbreviations: ELF-MF, extremely low-frequency magnetic fields

a Single exposure model where each agent was added one at a time and adjusted for socioeconomic status (SES).

${ }^{\mathrm{b}}$ Multiple exposure model where all agents were added simultaneously and adjusted for SES.

${ }^{c}$ The following agents were highly correlated (Spearman correlation $>0.80$ ), and therefore, were not included in the same model: all metals with each other and with welding fumes and benzo[a]pyrene; toluene, benzene and methylene chloride; benzene and gasoline (Supplementary Table 1). 
Table 3. Odds ratios (OR) and $95 \%$ confidence intervals $(95 \% \mathrm{Cl})$ for multilevel exposure to selected occupational agents and breast cancer in men.

\begin{tabular}{|c|c|c|c|c|c|c|c|c|}
\hline \multirow{2}{*}{ Agent $^{\text {a b }}$} & \multirow{2}{*}{$\begin{array}{c}\text { Case, } \\
\text { N }\end{array}$} & \multirow{2}{*}{$\begin{array}{c}\text { Control, } \\
\mathbf{N}\end{array}$} & \multicolumn{3}{|c|}{ Model $1^{\mathrm{c}}$} & \multicolumn{3}{|c|}{ Model $2^{\text {de }}$} \\
\hline & & & OR $^{f}$ & $95 \% \mathrm{Cl}$ & p-trend & $\mathbf{O R}^{\mathrm{f}}$ & $95 \% \mathrm{Cl}$ & p-trend \\
\hline \multicolumn{9}{|l|}{ Solvents } \\
\hline \multicolumn{9}{|l|}{ Benzene } \\
\hline$\leq 5.5$ & 55 & 297 & 0.92 & $0.68-1.24$ & & 0.90 & $0.59-1.37$ & \\
\hline $5.6-15.1$ & 47 & 234 & 1.00 & $0.73-1.38$ & & 0.82 & $0.49-1.38$ & \\
\hline$>15.1$ & 12 & 58 & 1.03 & $0.55-1.94$ & 0.89 & 0.78 & $0.38-1.63$ & 0.38 \\
\hline \multicolumn{9}{|c|}{ 1,1,1-trichloroethane } \\
\hline$\leq 5.6$ & 122 & 623 & 0.98 & $0.80-1.20$ & & 1.18 & $0.70-1.98$ & \\
\hline $5.7-13$ & 41 & 190 & 1.10 & $0.77-1.55$ & & 1.36 & $0.74-2.50$ & \\
\hline$>13$ & 18 & 91 & 1.01 & $0.60-1.69$ & 0.83 & 1.10 & $0.50-2.41$ & 0.73 \\
\hline \multicolumn{9}{|c|}{ Methylene chloride } \\
\hline$\leq 12.5$ & 51 & 294 & 0.87 & $0.64-1.18$ & & 0.81 & $0.42-1.56$ & \\
\hline $12.6-76.4$ & 52 & 220 & 1.18 & $0.87-1.62$ & & 0.99 & $0.51-1.96$ & \\
\hline$>76.4$ & 10 & 59 & 0.85 & $0.43-1.67$ & 0.88 & 0.65 & $0.25-1.70$ & 0.69 \\
\hline \multicolumn{9}{|c|}{ Perchloroethylene } \\
\hline$\leq 9.0$ & 8 & 56 & 0.70 & $0.33-1.46$ & & 0.59 & $0.25-1.41$ & \\
\hline $9.1-75.6$ & 5 & 46 & 0.54 & $0.22-1.37$ & & 0.31 & $0.11-0.88$ & \\
\hline$>75.6$ & 1 & 12 & 0.41 & $0.05-3.16$ & 0.07 & 0.37 & $0.04-3.51$ & 0.02 \\
\hline \multicolumn{9}{|l|}{ Toluene } \\
\hline$\leq 62.9$ & 53 & 304 & 0.87 & $0.64-1.17$ & & 0.68 & $0.33-1.38$ & \\
\hline $70-732$ & 52 & 233 & 1.11 & $0.82-1.51$ & & 1.18 & $0.67-2.06$ & \\
\hline$>732$ & 13 & 59 & 1.10 & $0.60-2.03$ & 0.76 & 1.13 & $0.45-2.85$ & 0.48 \\
\hline \multicolumn{9}{|c|}{ Trichloroethylene } \\
\hline$\leq 27.2$ & 56 & 308 & 0.90 & $0.67-1.21$ & & 1.19 & $0.75-1.90$ & \\
\hline $27.3-138$ & 54 & 237 & 1.17 & $0.86-1.58$ & & 1.46 & $0.86-2.49$ & \\
\hline$>138$ & 10 & 62 & 0.80 & $0.41-1.57$ & 0.94 & 1.55 & $0.64-3.76$ & 0.29 \\
\hline \multicolumn{9}{|l|}{ Metals } \\
\hline \multicolumn{9}{|l|}{ Chromium } \\
\hline$\leq 24.4$ & 132 & 613 & 1.08 & $0.89-1.33$ & & 1.19 & $0.85-1.67$ & \\
\hline $24.5-152$ & 93 & 503 & 0.93 & $0.74-1.17$ & & 1.03 & $0.62-1.72$ & \\
\hline$>152$ & 20 & 129 & 0.77 & $0.48-1.23$ & 0.42 & 0.90 & $0.44-1.85$ & 0.90 \\
\hline \multicolumn{9}{|l|}{ Iron } \\
\hline$\leq 5.1$ & 103 & 528 & 0.97 & $0.77-1.21$ & & 1.72 & $0.78-3.81$ & \\
\hline $5.2-55$ & 77 & 427 & 0.90 & $0.70-1.16$ & & 1.48 & $0.69-3.18$ & \\
\hline$>55$ & 23 & 104 & 1.11 & $0.70-1.75$ & 0.66 & 2.04 & $0.72-5.78$ & 0.44 \\
\hline \multicolumn{9}{|l|}{ Nickel } \\
\hline$\leq 12.8$ & 97 & 540 & 0.89 & $0.71-1.12$ & & 0.58 & $0.27-1.22$ & \\
\hline $12.9-73$ & 82 & 426 & 0.95 & $0.74-1.22$ & & 0.56 & $0.26-1.20$ & \\
\hline$>73$ & 22 & 106 & 1.03 & $0.65-1.63$ & 0.59 & 0.92 & $0.36-2.34$ & 0.93 \\
\hline \multicolumn{9}{|l|}{ Lead } \\
\hline$\leq 4.2$ & 126 & 742 & 0.84 & $0.69-1.03$ & & 0.84 & $0.57-1.25$ & \\
\hline $4.3-12.1$ & 125 & 568 & 1.10 & $0.90-1.35$ & & 1.15 & $0.76-1.74$ & \\
\hline$>12.1$ & 35 & 139 & 1.25 & $0.86-1.82$ & 0.45 & 1.56 & $0.99-2.46$ & 0.06 \\
\hline
\end{tabular}




\begin{tabular}{|c|c|c|c|c|c|c|c|c|}
\hline \multirow{2}{*}{\multicolumn{9}{|c|}{ Exhaust gas }} \\
\hline & & & & & & & & \\
\hline \multicolumn{9}{|c|}{ Diesel exhaust } \\
\hline$\leq 0.7$ & 133 & 715 & 0.91 & $0.75-1.11$ & & 0.91 & $0.73-1.13$ & \\
\hline $0.8-2.2$ & 113 & 564 & 0.98 & $0.80-1.22$ & & 1.05 & $0.80-1.39$ & \\
\hline$>2.2$ & 31 & 139 & 1.10 & $0.74-1.64$ & 0.90 & 1.09 & $0.62-1.91$ & 0.95 \\
\hline \multicolumn{9}{|c|}{ Gasoline exhaust } \\
\hline$\leq 1.7$ & 36 & 178 & 1.02 & $0.71-1.48$ & & 1.67 & $0.65-4.29$ & \\
\hline $1.8-4.3$ & 30 & 140 & 1.08 & $0.72-1.61$ & & 1.13 & $0.42-2.99$ & \\
\hline$>4.3$ & 5 & 38 & 0.63 & $0.25-1.60$ & 0.80 & 0.53 & $0.16-1.73$ & 0.27 \\
\hline \multicolumn{9}{|l|}{ Other agents } \\
\hline \multicolumn{9}{|c|}{ Formaldehyde } \\
\hline$\leq 0.2$ & 71 & 444 & 0.82 & 0.63-1.06 & & 0.94 & $0.68-1.31$ & \\
\hline $0.3-3.2$ & 67 & 344 & 0.96 & $0.74-1.26$ & & 0.93 & $0.63-1.39$ & \\
\hline$>3.2$ & 18 & 85 & 1.04 & $0.62-1.73$ & 0.51 & 0.80 & $0.34-1.89$ & 0.68 \\
\hline \multicolumn{9}{|c|}{ Benzo[a]pyrene } \\
\hline$\leq 0.3$ & 84 & 430 & 0.97 & $0.76-1.25$ & & 1.01 & $0.61-1.64$ & \\
\hline $0.4-2.1$ & 63 & 348 & 0.89 & $0.68-1.18$ & & 0.80 & $0.48-1.34$ & \\
\hline$>2.1$ & 12 & 91 & 0.66 & $0.36-1.21$ & 0.17 & 0.80 & $0.33-1.93$ & 0.36 \\
\hline \multicolumn{9}{|c|}{ Bitumen fumes } \\
\hline$\leq 0.3$ & 8 & 55 & 0.74 & $0.35-1.57$ & & 0.77 & $0.34-1.73$ & \\
\hline $0.4-3.1$ & 8 & 41 & 0.95 & $0.44-2.03$ & & 1.02 & $0.41-2.51$ & \\
\hline$>3.1$ & 1 & 12 & 0.45 & $0.06-3.48$ & 0.41 & 0.88 & $0.10-7.74$ & 0.69 \\
\hline \multicolumn{9}{|l|}{ Asbestos } \\
\hline$\leq 2$ & 167 & 943 & 0.85 & $0.71-1.02$ & & 0.89 & $0.70-1.14$ & \\
\hline $3-17.4$ & 129 & 754 & 0.83 & $0.68-1.02$ & & 0.72 & $0.50-1.04$ & \\
\hline$>17.4$ & 30 & 192 & 0.76 & $0.52-1.13$ & 0.01 & 0.74 & $0.39-1.38$ & 0.17 \\
\hline \multicolumn{9}{|l|}{ Silica dust } \\
\hline$\leq 1.2$ & 74 & 421 & 0.89 & $0.69-1.15$ & & 1.22 & $0.83-1.81$ & \\
\hline $1.3-6.6$ & 48 & 348 & 0.69 & $0.50-0.93$ & & 1.07 & $0.69-1.68$ & \\
\hline$>6.6$ & 13 & 86 & 0.75 & $0.41-1.34$ & 0.01 & 0.91 & $0.44-1.88$ & 0.74 \\
\hline \multicolumn{9}{|c|}{ Sulphur dioxide } \\
\hline$\leq 9.4$ & 16 & 102 & 0.79 & $0.47-1.34$ & & 0.87 & $0.49-1.52$ & \\
\hline $9.5-37$ & 14 & 79 & 0.91 & $0.51-1.61$ & & 0.78 & $0.38-1.58$ & \\
\hline$>37$ & 2 & 22 & 0.45 & $0.11-1.92$ & 0.23 & 0.44 & $0.09-2.14$ & 0.68 \\
\hline \multicolumn{9}{|c|}{ Night-shift work } \\
\hline$\leq 5.1$ & 168 & 905 & 0.90 & $0.75-1.08$ & & 0.90 & $0.74-1.11$ & \\
\hline $5.2-21.2$ & 128 & 729 & 0.85 & $0.69-1.03$ & & 0.87 & $0.69-1.10$ & \\
\hline$>21.2$ & 37 & 178 & 1.00 & $0.70-1.44$ & 0.14 & 1.27 & $0.82-1.97$ & 0.23 \\
\hline \multicolumn{9}{|l|}{ ELF-MF } \\
\hline$\leq 38.4$ & 321 & 1570 & 1.02 & $0.88-1.18$ & & 1.01 & $0.85-1.21$ & \\
\hline $38.5-139$ & 259 & 1253 & 1.02 & $0.87-1.19$ & & 0.99 & $0.82-1.20$ & \\
\hline$>139$ & 45 & 334 & 0.68 & $0.49-0.93$ & 0.27 & 0.67 & $0.45-0.98$ & 0.25 \\
\hline \multicolumn{9}{|c|}{ Physical workload } \\
\hline$\leq 6.4$ & 466 & 2429 & 0.81 & $0.71-0.93$ & & 0.84 & $0.71-0.99$ & \\
\hline $6.5-20$ & 334 & 1982 & 0.72 & $0.62-0.84$ & & 0.82 & $0.65-1.02$ & \\
\hline$>20$ & 75 & 504 & 0.63 & $0.48-0.82$ & $<0.01$ & 0.68 & $0.48-0.96$ & $<0.01$ \\
\hline
\end{tabular}




\begin{tabular}{|c|r|r|r|r|r|r|r|r|}
\hline Wood dust & & & & & & & & \\
\hline$\leq 10.8$ & 58 & 291 & 1.02 & $0.77-1.37$ & & 1.12 & $0.80-1.58$ & \\
\hline $10.9-44.2$ & 39 & 229 & 0.85 & $0.60-1.20$ & & 0.95 & $0.62-1.46$ & \\
\hline$>44.2$ & 14 & 55 & 1.29 & $0.71-2.32$ & 0.88 & 1.26 & $0.60-2.64$ & 0.19 \\
\hline Welding fumes & & & & & & & & \\
\hline$\leq 3.0$ & 92 & 539 & 0.86 & $0.68-1.08$ & & 1.19 & $0.55-2.59$ & \\
\hline $3.1-142$ & 88 & 416 & 1.04 & $0.82-1.33$ & & 1.86 & $0.89-3.91$ & \\
\hline$>142$ & 23 & 104 & 1.11 & $0.70-1.75$ & 0.96 & 2.25 & $0.80-6.34$ & 0.02 \\
\hline Ultraviolet radiation & & & & & & & & \\
\hline$\leq 5510$ & 241 & 1345 & 0.85 & $0.73-0.99$ & & 0.95 & $0.78-1.17$ & \\
\hline $5511-9720$ & 169 & 1108 & 0.72 & $0.60-0.86$ & & 0.84 & $0.66-1.08$ & \\
\hline$>9720$ & 49 & 259 & 0.88 & $0.63-1.21$ & $<0.01$ & 1.07 & $0.69-1.68$ & 0.58 \\
\hline
\end{tabular}

Abbreviations: ELF-MF, extremely low-frequency magnetic fields;

${ }^{a}$ Exposure agents were categorized by using 50th and 90th percentiles of exposure distribution among exposed controls.

${ }^{\mathrm{b}}$ Unit of exposure was parts per million years (ppm years) in the workroom air for solvents, gasoline, formaldehyde, sulphur dioxide; milligram of cubic meter years $\left(\mathrm{mg} / \mathrm{m}^{3}\right.$ years) in the workroom air for iron, diesel, benzo[a]pyrene, bitumen fumes, silica dust, wood dust, welding fumes; microgram per cubic meter years $\left(\mu \mathrm{g} / \mathrm{m}^{3}\right)$ in the workroom air for nickel, chromium; micromoles in litre of blood years ( $\mu \mathrm{mol} /$ litre) for lead; fibres per cubic centimetre $\left(\mathrm{f} / \mathrm{cm}^{3}\right)$ for asbestos; joule per square meters $\left(\mathrm{J} / \mathrm{m}^{2}\right)$ for ultraviolet radiation; microTesla years ( $\mu T$ years) for ELF-MF; perceived physical workload years (ppwl years) for physical workload (27); probability of night-work years (nigw years) for night-shift work (28).

c Single exposure model where each agent was added one at a time and adjusted for socioeconomic status (SES).

${ }^{d}$ Multiple exposure model where all agents were added simultaneously and adjusted for SES.

${ }^{\mathrm{e}}$ The following agents were highly correlated (Spearman correlation $>0.80$ ) and therefore, were not included in the same model: all metals with each other and with welding fumes and benzo[a]pyrene; toluene, benzene and methylene chloride; benzene and gasoline (Supplementary Table 1).

${ }^{f}$ Reference category is unexposed group.

\section{Highlights}

- Male breast cancer (MBC) is a rare and understudied disease.

- We assessed associations between occupational agents and MBC in the current study.

- While no strong evidence was observed for other agents, physical activity at work was linked to $20-25 \%$ reduced $\mathrm{MBC}$ risk. 
Supplementary Table 1. Spearman correlation coefficients for the agents included in the study.

\begin{tabular}{|c|c|c|c|c|c|c|c|c|c|c|c|c|c|c|c|c|c|c|c|c|c|c|c|c|}
\hline Agent $^{\mathrm{a}}$ & BENZ & ASB & BAP & CR & FORM & TCE & BITU & DEEX & $\mathrm{FE}$ & GASO & $\mathrm{MCH}$ & $\mathrm{NI}$ & PB & PER & QUAR & SO2 & TOLU & TRI & WELD & WOOD & UV & NIGW & $\begin{array}{l}\text { PPWL } \\
\end{array}$ & ELFMF \\
\hline BENZ & 1.00 & & & & & & & & & & & & & & & & & & & & & & & \\
\hline ASB & 0.36 & 1.00 & & & & & & & & & & & & & & & & & & & & & & \\
\hline BAP & 0.42 & 0.31 & 1.00 & & & & & & & & & & & & & & & & & & & & & \\
\hline CR & 0.47 & 0.40 & 0.73 & 1.00 & & & & & & & & & & & & & & & & & & & & \\
\hline FORM & 0.19 & 0.19 & 0.11 & 0.28 & 1.00 & & & & & & & & & & & & & & & & & & & \\
\hline TCE & 0.62 & 0.28 & 0.64 & 0.73 & 0.20 & 1.00 & & & & & & & & & & & & & & & & & & \\
\hline BITU & 0.06 & 0.04 & 0.06 & -0.01 & 0.05 & -0.01 & 1.00 & & & & & & & & & & & & & & & & & \\
\hline DEEX & 0.36 & 0.12 & 0.30 & 0.17 & -0.09 & 0.25 & 0.21 & 1.00 & & & & & & & & & & & & & & & & \\
\hline $\mathrm{FE}$ & 0.34 & 0.37 & 0.82 & 0.88 & 0.10 & 0.63 & -0.01 & 0.22 & 1.00 & & & & & & & & & & & & & & & \\
\hline GASO & 0.77 & 0.34 & 0.56 & 0.42 & -0.03 & 0.55 & 0.00 & 0.50 & 0.47 & 1.00 & & & & & & & & & & & & & & \\
\hline MCH & 0.85 & 0.39 & 0.43 & 0.51 & 0.29 & 0.72 & 0.06 & 0.32 & 0.35 & 0.70 & 1.00 & & & & & & & & & & & & & \\
\hline $\mathrm{NI}$ & 0.35 & 0.38 & 0.80 & 0.87 & 0.11 & 0.64 & 0.00 & 0.22 & 0.96 & 0.49 & 0.37 & 1.00 & & & & & & & & & & & & \\
\hline PB & 0.48 & 0.41 & 0.67 & 0.81 & 0.25 & 0.71 & 0.02 & 0.20 & 0.78 & 0.44 & 0.55 & 0.78 & 1.00 & & & & & & & & & & & \\
\hline PER & 0.04 & 0.03 & 0.01 & 0.03 & 0.08 & 0.20 & 0.01 & 0.00 & 0.03 & 0.00 & 0.10 & 0.04 & 0.14 & 1.00 & & & & & & & & & & \\
\hline QUAR & -0.03 & 0.54 & 0.09 & 0.03 & 0.01 & -0.03 & 0.06 & -0.04 & 0.04 & -0.03 & -0.03 & 0.08 & 0.06 & -0.02 & 1.00 & & & & & & & & & \\
\hline SO2 & 0.00 & 0.03 & 0.11 & 0.15 & 0.01 & 0.04 & 0.00 & 0.01 & 0.16 & -0.01 & 0.00 & 0.19 & 0.12 & 0.03 & 0.16 & 1.00 & & & & & & & & \\
\hline TOLU & 0.92 & 0.37 & 0.41 & 0.49 & 0.23 & 0.64 & 0.06 & 0.35 & 0.33 & 0.74 & 0.87 & 0.34 & 0.50 & 0.08 & -0.03 & 0.01 & 1.00 & & & & & & & \\
\hline TRI & 0.14 & 0.12 & 0.49 & 0.59 & 0.02 & 0.62 & -0.02 & 0.05 & 0.64 & 0.15 & 0.13 & 0.62 & 0.53 & 0.30 & -0.01 & 0.05 & 0.12 & 1.00 & & & & & & \\
\hline WELD & 0.36 & 0.40 & 0.80 & 0.87 & 0.10 & 0.62 & -0.01 & 0.23 & 1.00 & 0.50 & 0.37 & 0.96 & 0.78 & 0.03 & 0.03 & 0.15 & 0.35 & 0.61 & 1.00 & & & & & \\
\hline WOOD & -0.02 & 0.24 & -0.05 & 0.02 & 0.25 & -0.03 & -0.02 & -0.09 & -0.07 & -0.04 & -0.01 & -0.07 & -0.09 & -0.02 & 0.35 & -0.02 & -0.01 & -0.05 & -0.07 & 1.00 & & & & \\
\hline UV & -0.05 & 0.25 & -0.06 & 0.00 & 0.20 & -0.08 & -0.02 & -0.18 & -0.03 & -0.10 & -0.02 & -0.03 & -0.01 & -0.04 & 0.26 & -0.08 & 0.04 & -0.05 & -0.03 & 0.10 & 1.00 & & & \\
\hline NIGW & 0.02 & -0.06 & 0.06 & 0.03 & 0.03 & -0.03 & 0.04 & 0.32 & 0.04 & 0.00 & 0.00 & 0.04 & 0.05 & 0.05 & 0.01 & 0.32 & 0.02 & -0.03 & 0.03 & -0.05 & -0.14 & 1.00 & & \\
\hline PPWL & 0.07 & 0.35 & 0.17 & 0.25 & 0.19 & 0.16 & 0.00 & -0.15 & 0.22 & 0.05 & 0.09 & 0.21 & 0.18 & 0.00 & 0.32 & 0.02 & 0.09 & 0.17 & 0.21 & 0.20 & 0.64 & -0.16 & 1.00 & \\
\hline EMF & 0.17 & 0.17 & 0.42 & 0.42 & 0.24 & 0.30 & -0.02 & 0.16 & 0.48 & 0.23 & 0.17 & 0.47 & 0.43 & 0.11 & -0.05 & 0.21 & 0.18 & 0.31 & 0.48 & -0.09 & 0.09 & 0.19 & -0.02 & 1.00 \\
\hline
\end{tabular}

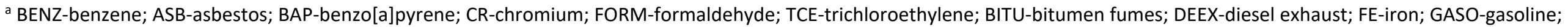

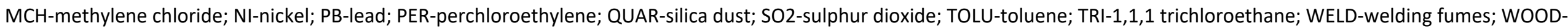
wood dust; UV-ultraviolet radiation; NIGW-night-shift work; PPWL-physical workload; ELFMF-extremely low-frequency magnetic fields. 
Supplementary Table 2. Odds ratios (OR) and 95\% confidence intervals $(95 \% \mathrm{Cl})$ for exposure to selected occupational agents and breast cancer in men. Analysis with adjustment for the life-style related factors in the Finnish data.

\begin{tabular}{|c|c|c|c|c|c|c|c|c|}
\hline \multirow{2}{*}{ Agent } & \multirow{2}{*}{$\begin{array}{c}\text { Case, } \\
\mathbf{N}\end{array}$} & \multirow{2}{*}{$\begin{array}{c}\text { Control, } \\
\text { N }\end{array}$} & \multicolumn{3}{|c|}{ Model $1^{a}$} & \multicolumn{3}{|c|}{ Model $2^{b c}$} \\
\hline & & & OR & $95 \% \mathrm{Cl}$ & p-value & OR & $95 \% \mathrm{Cl}$ & p-value \\
\hline \multicolumn{9}{|l|}{ Solvents } \\
\hline \multicolumn{9}{|l|}{ Benzene } \\
\hline never & 291 & 1454 & 1.00 & & & 1.00 & & \\
\hline ever & 17 & 86 & 0.98 & $0.56-1.69$ & 0.93 & 1.00 & $0.23-4.39$ & 0.99 \\
\hline \multicolumn{9}{|c|}{ 1,1,1-trichloroethane } \\
\hline never & 275 & 1403 & 1.00 & & & 1.00 & & \\
\hline ever & 33 & 137 & 1.09 & $0.72-1.68$ & 0.67 & 1.87 & $0.40-8.62$ & 0.43 \\
\hline \multicolumn{9}{|c|}{ Methylene chloride } \\
\hline never & 292 & 1447 & 1.00 & & & 1.00 & & \\
\hline ever & 16 & 93 & 0.79 & $0.46-1.38$ & 0.42 & 0.52 & $0.11-2.37$ & 0.39 \\
\hline \multicolumn{9}{|c|}{ Perchloroethylene } \\
\hline never & 308 & 1525 & 1.00 & & & 1.00 & & \\
\hline ever & 0 & 15 & - & - & - & - & - & 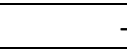 \\
\hline \multicolumn{9}{|l|}{ Toluene } \\
\hline never & 289 & 1449 & 1.00 & & & 1.00 & & \\
\hline ever & 19 & 91 & 0.99 & $0.59-1.67$ & 0.98 & 1.99 & $0.48-8.23$ & 0.34 \\
\hline \multicolumn{9}{|c|}{ Trichloroethylene } \\
\hline never & 283 & 1436 & 1.00 & & & 1.00 & & \\
\hline ever & 25 & 104 & 1.11 & $0.68-1.79$ & 0.68 & 1.12 & $0.22-5.71$ & 0.89 \\
\hline \multicolumn{9}{|l|}{ Metals } \\
\hline \multicolumn{9}{|l|}{ Chromium } \\
\hline never & 259 & 1326 & 1.00 & & & 1.00 & & \\
\hline ever & 49 & 214 & 1.12 & $0.78-1.61$ & 0.54 & 1.01 & $0.53-1.91$ & 0.98 \\
\hline \multicolumn{9}{|l|}{ Iron } \\
\hline never & 270 & 1383 & 1.00 & & & 1.00 & & \\
\hline ever & 38 & 157 & 1.14 & $0.76-1.71$ & 0.53 & 1.83 & $0.21-16.36$ & 0.58 \\
\hline \multicolumn{9}{|l|}{ Nickel } \\
\hline never & 269 & 1368 & 1.00 & & & 1.00 & & \\
\hline ever & 39 & 172 & 1.06 & $0.71-1.57$ & 0.78 & 6.03 & $0.07-5.12$ & 0.64 \\
\hline \multicolumn{9}{|l|}{ Lead } \\
\hline never & 261 & 1312 & 1.00 & & & 1.00 & & \\
\hline ever & 47 & 228 & 0.92 & $0.64-1.32$ & 0.66 & 0.65 & $0.27-1.56$ & 0.34 \\
\hline \multicolumn{9}{|c|}{ Exhaust gas } \\
\hline \multicolumn{9}{|c|}{ Diesel exhaust } \\
\hline never & 265 & 1300 & 1.00 & & & 1.00 & & \\
\hline ever & 43 & 240 & 0.92 & $0.63-1.33$ & 0.65 & 0.99 & $0.60-1.65$ & 0.99 \\
\hline \multicolumn{9}{|c|}{ Gasoline exhaust } \\
\hline never & 298 & 1492 & 1.00 & & & 1.00 & & \\
\hline ever & 10 & 48 & 0.98 & $0.48-2.01$ & 0.97 & 0.68 & $0.13-3.59$ & 0.65 \\
\hline \multicolumn{9}{|c|}{ Other agents } \\
\hline \multicolumn{9}{|c|}{ Formaldehyde } \\
\hline never & 282 & 1354 & 1.00 & & & 1.00 & & \\
\hline ever & 26 & 186 & 0.73 & $0.47-1.14$ & 0.16 & 0.67 & $0.37-1.19$ & 0.18 \\
\hline
\end{tabular}




\begin{tabular}{|c|c|c|c|c|c|c|c|c|}
\hline \multicolumn{9}{|c|}{ Benzo[a]pyrene } \\
\hline never & 285 & 1414 & 1.00 & & & 1.00 & & \\
\hline ever & 23 & 126 & 0.85 & $0.52-1.36$ & 0.49 & 0.63 & $0.28-1.39$ & 0.25 \\
\hline \multicolumn{9}{|c|}{ Bitumen fumes } \\
\hline never & 303 & 1509 & 1.00 & & & 1.00 & & \\
\hline ever & 5 & 31 & 0.89 & $0.34-2.30$ & 0.81 & 1.28 & $0.43-3.79$ & 0.65 \\
\hline \multicolumn{9}{|l|}{ Asbestos } \\
\hline never & 238 & 1154 & 1.00 & & & 1.00 & & \\
\hline ever & 70 & 386 & 0.79 & $0.57-1.12$ & 0.18 & 1.06 & $0.65-1.73$ & 0.82 \\
\hline \multicolumn{9}{|l|}{ Silica dust } \\
\hline never & 282 & 1346 & 1.00 & & & 1.00 & & \\
\hline ever & 26 & 194 & 0.58 & $0.36-0.92$ & 0.02 & 0.39 & $0.19-0.83$ & 0.01 \\
\hline \multicolumn{9}{|c|}{ Sulphur dioxide } \\
\hline never & 303 & 1502 & 1.00 & & & 1.00 & & \\
\hline ever & 5 & 38 & 0.64 & $0.25-1.65$ & 0.35 & 0.73 & $0.26-2.07$ & 0.56 \\
\hline \multicolumn{9}{|c|}{ Night-shift work } \\
\hline never & 253 & 1212 & 1.00 & & & 1.00 & & \\
\hline ever & 55 & 328 & 0.77 & $0.55-1.09$ & 0.14 & 0.76 & $0.49-1.16$ & 0.20 \\
\hline \multicolumn{9}{|l|}{ ELF-MF } \\
\hline never & 192 & 985 & 1.00 & & & 1.00 & & \\
\hline ever & 116 & 555 & 1.01 & $0.77-1.32$ & 0.92 & 1.02 & $0.49-1.16$ & 0.92 \\
\hline \multicolumn{9}{|c|}{ Physical workload } \\
\hline never & 137 & 560 & 1.00 & & & 1.00 & & \\
\hline ever & 171 & 980 & 0.69 & $0.49-0.97$ & 0.03 & 0.60 & $0.39-0.94$ & 0.02 \\
\hline \multicolumn{9}{|c|}{ Wood dust } \\
\hline never & 286 & 1415 & 1.00 & & & 1.00 & & \\
\hline ever & 22 & 125 & 0.97 & $0.59-1.59$ & 0.90 & 1.46 & $0.77-2.79$ & 0.25 \\
\hline \multicolumn{9}{|c|}{ Welding fumes } \\
\hline never & 270 & 1383 & 1.00 & & & 1.00 & & \\
\hline ever & 38 & 157 & 1.14 & $0.76-1.71$ & 0.53 & 1.84 & $0.21-16.36$ & 0.59 \\
\hline \multicolumn{9}{|c|}{ Ultraviolet radiation } \\
\hline never & 205 & 892 & 1.00 & & & 1.00 & & \\
\hline ever & 103 & 648 & 0.96 & $0.69-1.33$ & 0.82 & 1.22 & $0.82-1.80$ & 0.33 \\
\hline
\end{tabular}

Abbreviations: ELF-MF, extremely low-frequency magnetic fields

${ }^{a}$ Single exposure model where each agent was added one at a time and adjusted for socioeconomic status SES).

${ }^{\mathrm{b}}$ Multiple exposure model where all agents were added simultaneously and adjusted for SES.

c The following agents were highly correlated (Spearman correlation $>0.80$ ), and therefore, were not included in the same model: all metals with each other and with welding fumes and benzo[a]pyrene; toluene, benzene and methylene chloride; benzene and gasoline (Supplementary Table 1). 